\title{
Sexuality and Governmentality
}

\author{
Teza Yudha / Government Sciences Department \\ University of Singaperbangsa Karawang, Indonesia \\ email: teza.yudha@staff.unsika.ac.id
}

\author{
Dede Mariana / Public Policy Research Center of \\ Padjadjaran University, Indonesia \\ email:d.mar@unpad.ac.id
}

\begin{abstract}
The government's forced sexuality setting takes place almost everywhere in Indonesia. Local governments ratify it with various policies through local regulations. Any illegal fulfillment of sexual desire is instantly wiped out. Whereas usually when the fulfillment of this desire eradicated, even transformed into various forms of efforts to fulfill the desire in free sex and the practice of prostitution that can't be rejected. This research was located in Bandung City to study phenomenology 'sexuality and relation with governmental power. Researchers identify in this city there are women sex workers who are quite a lot. The results showed that there are at least three forms of prostitution in Bandung: Permanent, Open, and Covert. Until now, although the city of Bandung has closed Saritem a prostitution site that stands permanently standing, and handling prostitution through Regional Regulation No. 3 and 11 of 2005 on Orderliness, Beauty, and Hygiene. However, all these attempts failed to address the three forms of prostitution. The closure of Saritem and the capture of a prostitute woman could not solve this problem. Because prostitutes are just victims of poverty and helplessness born from the "host's womb", which is fertilized by the "pimp's sperm". So in fact prostitution is a child of injustice resulting from the dark relationship of pimping affairs with the power of the government.
\end{abstract}

\section{Keywords-sexuality, prostitutions, government.}

\section{INTRODUCTION}

Hundreds of years duration of sexuality appear and discussed in various currents of thought with various issues and discourses worldwide. Throughout its history of sexuality discussed and became an interesting debate for the general public, clerics, academics, to politicians. Sexuality is present as an instrument that can create public irregularities, social problems and diseases, amoral, and even madness for some people. However, others believe that the freedom of sexuality is a necessity for every individual as existence that must be fulfilled, to be human is to accept the passions of love and sexual desire as part of life, and maintain sexual freedom as a romantic civilization. Substantially sexuality is a major part of the desires of bodily fulfillment. It is part of the body's consumption. Borrowing the term from Pasi Falk (1994) sex is also part of the "corporeality of the body". Since prehistoric times sexuality is considered as an instinctive part of nature's necessity in order to continue the process of survival (Kadir, 2007: 1).

Foucault shows that sexuality is not merely an inward impulse or biological, but a form of behavior and mind that is subdued or forged by power relations called governmentality. That is, power is internalized in the form of a social body as well as a disciplinary power model that internalizes power within an individual's body. ${ }^{1}$ Furthermore, according to Foucault is a form of legal decision and order that the freedom of sexuality must be eradicated and eliminated by power (government) through repressive measures. The ambiguity embodied in human attitudes is their conception of sexuality being two-faced, sexuality capable of being an outlet for desire and desires, but on the other side sexuality is also repressed. The free sex phenomenon that causes pre-married pregnancy in Indonesia by youth couples deliberately as part of resistance as well as a way out when both parties to their parents didn't approve the relationship status between the two. In overcoming the problem, impregnating the female partner is the easiest way, because then sometimes the parent will become more let, be understanding and even agree on the status of their relationship. Similarly, in other cases the number of women who prostitute themselves for several things, such as: Economic problems, disappointment of the partner who abandoned him, poverty, as well as the demands of responsibility towards his family or brother, as well as the fulfillment of lifestyle. So they choose to prostitute themselves as a way out of the problems that holding. This case shows that sex can be a way out for the problem of the desire of the body, although in the end the expression of sexuality will again be rejected, such as in the form of prohibition of prostitution, social exclusion, and of course the actions of the government.

So another phenomenon of this restriction of sexuality with more lively surfaces, namely the development of prostitution with a variety of motives of dark and disguised activities, prostitution fame sex-frozen sex that became the peak of one's enjoyment pleases. The sex industry in Indonesia is capable of earning US $\$ 3.3$ billion, or about 42.9 trillion Rupiah each year (estimated US \$ 1 / IDR 13,000, 2016), something quite surprising for an underground industry (Lim, 2005: 233). As an illustration, in Indonesia alone this phenomenon we can see data from the Ministry of Health of the Republic of Indonesia which recorded until the end of 2012 alone there are 6.7 million Indonesian men who became customers of commercial sex workers most at high risk to spread HIV-AIDS death diseases. On the other hand, there are about 230,000 women sex worker scattered throughout Indonesia, with an increasing number of each year. ${ }^{2}$ Then the a priori became stronger when the Ministry of Social Affairs showed 168 locations of prostitution recorded in the midst of society throughout the

\footnotetext{
${ }^{1}$ Mudhoffir, Abdil Mughis, "Teori Kekuasaan Michel Foucault: Tantangan bagi Sosiologi Politik", Jurnal Sosiologi MASYARAKAT 18-01: 75 100, 2007:86.

${ }^{2}$ Pikiran Rakyat, 10 April 2013:8.
} 
territory of Indonesia, but only 39 locations that the government could settle for 70 years of independent Indonesia. ${ }^{3}$

The city of Bandung throughout its history has experienced various complex dynamics in the actions of its government by strictly prohibiting the freedom of sexuality of the community let alone the activities of prostitution. However, in this city access to fulfillment of sexual needs still easily we can get, the facility is spread in every corner of the city with various forms of entertainment activities that support and grow in the creation of a sparkling and full of enjoyment. Bandung City Government until now has not been able to handle the phenomenon of prostitution which is increasingly widespread day by various motives of practice and transactions are diverse and almost not controlled structurally. Even up to the time this study was written, the city of Bandung does not yet have a regional regulation that specifically regulates the phenomenon of prostitution following its handling. The inconsistency of the Bandung government in addressing the phenomenon of prostitution makes this issue rarely discussed and the arrangement is only affixed to Regional Regulation Number 3 and Number 11 Year 2005 on the Implementation of Order, Cleanliness and Beauty. With the policy, the City Government of Bandung only looked at the phenomenon of prostitution from the point of immorality that violates the order. Unconsciously repressive acts perpetrated by "ransacking" the prostitute's nest in one place causes prostitutes to spread to other, more vague and veiled places. Further prostitution is widespread, dark, and not visible in the "visible" it will be more difficult to handle. The number of cases of prostitution recorded every year continues to increase, the various locations are used as a place of pervert, prostitution and other free sex as can't be eliminated as it continues to grow along with several other aspects to support its existence, although routinely the government carried out the operation of destroyer, filter to the closure of the location prostitution, but in fact the place is still standing and crowded visited by visitors to the present.

To examine why this phenomenon of prostitution continues, we can analyze it by reconstructing several theories. If Freud emphasizes that human behavior is derived from the drive of libido, then it is different from what Foucault believes. Every individual within each society has a political rather than an institutional but inherent interest in realizing his will, fighting for his rights and improving his living standards both socially and economically, to freedom in fulfilling sexual needs, this comes from the biopower that each of these individuals have it. Governmentality is present as a representation of government power to subdue and regulate the various forms of behavior derived from the bio-power. Thus the state can actually intervene against the behavior of its people. However, the extent to which the intervention may be exercised by the State is limited by not harming individual rights and social justice.

Thus, it becomes a fundamental requirement for researchers to create a framework that analyzes the behavioral arrangements of the community up to the analysis of policy implementation through the methods offered by Mazmanian

${ }^{3}$ Kompas, 2 January 2016:7. and Sabatier to review the policies that have been implemented by the Government of Bandung as stipulated in Regional Regulation No. 3 and 11 on Order, Hygiene and Beauty in handling prostitution. No exaggeration, later analysis of policy implementation is expected to find an effort and new alternatives effective in dealing with prostitution in the city of Bandung is growing this. Furthermore Mazmanian and Sabatier explains, there are at least three aspects approach in making an analysis of policy implementation. Components of the three aspects are used as a reference in starting the logic of an analysis process. Although it looks simple, from these three aspects there are several sub-aspects that are technical and researchers consider appropriate enough to be applied to analyze an implementation of policies handling prostitution in the city of Bandung. The concepts are constructed into abstractions which require some formulation of theories and sociological concepts to see this phenomenon from various interrelated points of view in order to understand the problem of research into a real (phenomenological) thing.

To make an analysis of policy implementation in this study is to examine how the three aspects below play a role in playing the policy implementation process: (1) Easy to control problems, (2) policy ability to structure implementation process, (3) Aspects outside the policy that affect the policy process (Agustino, 2008: 144). Implementation of the policy is an effort to realize a decision or agreement set previously by the government, in this case is the handling of prostitution in the city of Bandung. Furthermore, researchers also explore various information relating to the sexuality and power of government from various sources with the aim to further explore the problem in reviewing a phenomenon that is quite complicated, thus the researchers summarize the results of scientific research from several sources, including: Then distinguish this research with the previous studies above, are: phenomenon of prostitution in the city of Bandung viewed from the point of view of Government Science. Thus, we can see how the existence of the function (focus of interest The Government field) government role in the implementation of policies handling prostitution in the city of Bandung. Through its power, the government is authorized to intervene in prostitution phenomena as an expression of uncontrolled freedom of sexuality.

\section{METHOD}

This research used phenomenology study with qualitative method approach which comes from constructivism paradigm. Because viewed from the point of view and the formulation of the problem, the discussion, and the results to be achieved based on the phenomenological philosophy that prioritizes appreciation. In this case, in addition to conducting research with various techniques in qualitative methods of course, researchers also try to activate all the senses and feelings to capture the whole symptom completely, and build the meaning of a phenomenon of prostitution in the city of Bandung based on the perspective of the first person (the person who experienced it directly) either the prostitutes, or the government that handles, as well as other informants. Therefore, as 
Kuswarno discloses, "to obtain the essence of truth, it must break through the apparent phenomenon" (Kuswarno, 2013: 2).

Type in this research is "existential phenomenology studies" (Kuswarno, 2013: 27). That is, in the study of sexuality and power of this government, the phenomenology of the existence of sex workers or prostitutes will be explored in depth to find the essential meaning that may be found the answer through in-depth interview and observation full appreciation; including the experience before and after becoming a prostitute, the decisions and actions that underlie his prostitution, the awareness of his risky life choices, and how to intervene the government's power over this phenomenon, and seek an answer to the questions underlying this research: Why the phenomenon of prostitution in the city of Bandung is growing at precisely the moment the government handled through Regional Regulation No. 3 and No. 11 of 2005 on Orderliness, Cleanliness, and Beauty (Perda $\mathrm{K} 3)$.

\section{RESULT AND DISCUSSION}

\section{A. A Reproduction Tool, not a Recreational Tool!}

Social phenomenon that occurs in the city of tourist destinations such as the city of Bandung can't be separated from the various practices of prostitution. The notion of prostitution is a form of sexual intercourse outside of marriage with a certain pattern, example to anyone openly and almost always with the payment of both matching and other sex activities that give satisfaction desired by the concerned (Bloch in Ihsan, 2006: 11). Prostitution that develops in general can be described into three kinds of categories such as Truong ever found in his research, namely: First, covert prostitution. This model is usually business like beauty salon, hotel, discotheque, massage parlor, there are even those who practice in shelter or boarding house spread in various corners of the city and mingle with other residents. Places are generally a place of sex transactions.They work as usual with others, clothes and doing generally. Only one can be different: they want much money.

Second, open prostitution. The perpetrators of this activity openly showed his profession as a sex worker. Usually, they are on the street and in the dimly lit stalls. The phenomenon of prostitution is open, the advantages of potential customers directly meet and negotiate with sex workers. Third, permanent prostitution. This sex workers community can be known from its long-standing domicile. For example, in embroidery houses that are usually run by a group of people, in this place transactions are done more openly, in homes with sordid rooms facilities, beverage stalls that provide karaoke spots, gambling establishments, and various entertainment facilities others. In practice, permanent prostitution is inseparable from the role of landlords, pimps, pimps and brokers who have an important role in supporting the mechanism of prostitution.

Prostitution has become an object of arrangement under various forms of licensing in many countries (Chauvin in Truong, 1992:74), and arrangement is a form of government policy in handling various problems in society. Prostitution itself is defined in the Local Regulation of Bandung Number 3 and Number 11 Year 2005 regarding K3 as: Suspicious Tuna is a person who entered into a sexual relationship without being based on a legal marriage by expecting rewards or wages as a fringe benefit and disturbing public order.

The city of Bandung throughout its history has experienced various complex dynamics in the actions of its government with violent crimes of freedom of sexuality of society let alone prostitution activities. However, in this city access to the fulfillment of sexual needs still easily we can get, the facility is spread in every city with various forms of entertainment activities that support and grow in the creation of a sparkling and full of enjoyment.

Especially appeal of Bandung is also very attractive and make anyone fall in love with this city, with a sense of friendliness and courtesy of its citizens, who make feel at home for long even stay. Furthermore, who is not fascinated by the beauty of Parahyangan girls who are so charming, everything is created to fulfill the splendid beauty of Pasundan Land. "Pasundan Earth was born when God was smiling" (Brouwer, 2003:xvii).

Visitors from various regions of Indonesia come to Bandung in various ways and destinations: Travel, leisure, shopping, doing business, studying, to just looking for entertainment (including leisure and prostitution users). Data of tourist arrivals coming to Bandung every time continue to increase, in 2014 there are as many as 86,202,888 the number of visitors recorded into the city of Bandung through toll booths, terminals, stations and airports. Increased from 2013 to $83,838,979$, and 2012 with $80,501,064 .^{4}$

One of the most popular destinations and fashion destinations in Indonesia, Bandung happy to be the center of entertainment and prostitution activities in Indonesia, proven Saritem (the place of prostitution in Bandung) that ever happened officially by Bandung City Government in 2007 ago , but until now full of challenges. Saritem is still exist to serve service seekers from inside and outside Bandung city, Saritem based on sequence of study in field and various other information which is in process Saritem.

Covert prostitution that moves in the "underground" is not visible, but full is the most. As new researchers begin to follow this phenomenon, the image of its members has many unreal things from the darkness of prostitution, let alone a veiled one. Researchers only consider the information obtained from the imaginary thoughts of people who are not rational. However, the prostitution entity gradually reveals its reality: Call women, men, transvestites, lesbian and gay, threesome sex: men, women and transvestite, "ayam kampung - ayam kampus", and The Big Daddy with dozens of women on call, are a little covert prostitution phenomenon in Bandung that researchers know.

\footnotetext{
${ }^{4}$ Culture and Tourism Department of Bandung, 2015.
} 
Table 1. Mapping of the Number of Population Key to the Spread of HIV / AIDS in Bandung Year 2013. ${ }^{5}$

\begin{tabular}{cr}
\hline Type & Amount \\
\hline Women Sex Workers & 575 \\
Covert Sex Worker & 1,066 \\
Customer & 4,445 \\
Injecting Drug Users & 875 \\
Transvestite & 480 \\
Homosexual & 12,380 \\
\hline
\end{tabular}

Furthermore, the phenomenon of open prostitution is not only researchers find in one location only. Just like Jalan Kebon Jati, Jalan Otista precisely in the vicinity of Pasar Baru is the favorite location for men who are looking for an outlet for their desire, by slowing down the speed of the vehicles these men look at the beautiful girls of sex workers while searching for the taste of their lust. Encouragement that has been genitals with calls and seduction spoiled on the roadside of the lips of a red woman as if a source of thirsty washers will be sexual pleasure coveted. In his mind there is a belief that with different women, the warmth that is gained will be different.

Then the location of permanent prostitution in Bandung is the most famous Saritem. For years all efforts have been made by the government but did not make the pulse of prostitution life in Saritem stop. Even when the prostitutes' nest in Saritem was destroyed and closed, prostitution spread everywhere in silent and invisible ways. They operate in hotels and inns, and in rented houses that converge with residents. So it is not excessive presumably when researchers consider that prostitution in Bandung is developed. Women Sex Workers who practice prostitution in the city of Bandung until the Year 2015 estimate there are about 1900 people, and which has reached about 1300 people. While in the Year 2016 until June 13, 2016, the prostitutes who have been handled, namely: 415 Persons. ${ }^{6}$ These prostitutes are scattered in the city of Bandung and they practice prostitution permanently, openly, and most of them are in a circle of disguised prostitution.

When they offer the pleasure of their bodies to satisfy the lusts of men, not the least they gain from men is precisely violence and crime. Not to mention something they get almost every time not just from other people even from friends and from themselves as a woman: The feelings of humiliation become unlucky whores. The reasons for improving living standards are to bring them into extreme situations by prostituting themselves and being disregarded by ignoring health standards and replacing them with economic standards. A little lucky if the customer is willing to use a condom during sexual intercourse with him then. Thus it is not surprising that every year the spread of HIV / AIDS continues to increase. In

\footnotetext{
${ }^{5}$ The commitee of AIDS Tackling of Bandung, 2013.

${ }^{6}$ Interview with GS, Mawar Clinic Staff (Persatuan Keluarga Berencana Indonesia), Time: June 13, 2016, Time: 12:15 pm. Venue: Secretariat of Mawar Clinic (PKBI), Jl. Pasirkaliki, No. 26. Bandung City.
}

2015 alone recorded 3,625 people living with HIV / AIDS, an increase from 2014 as many as 3.375 people and in 2013 as many as 3111 people. ${ }^{7}$ When men hire prostitutes to have sexual intercourse is that they want the satisfaction they may not be able to with their partner, and having sex using a condom is a form of reduction of sexual pleasure, at least that's what most men think.

\section{B. Impotent Prostitution Handling}

Handling the practice of prostitution in the city of Bandung through Regional Regulation No. 3 and No. 11 of 2005 on Orderliness, Hygiene, and Beauty, is an effort Government of Bandung in eradicating the phenomenon of prostitution. However, phenomenologically until more than a decade since the issuance of the policy, up to the many times the dissolution of Saritem, it turns out the phenomenon in the field illustrates that prostitution in Bandung continues to grow. Trafficking and entering women sex workers into rehabilitation centers for several months is not enough to solve the problem of prostitution in Bandung, not even if only to suppress its growing development with various motives, systems and new modes that surround it. Implementation of prostitution policies is no other aim is to maintain order, hygiene and beauty in society so that the spiritual needs of society will be created social welfare. Politically, restricting the phenomenon of prostitution by arresting women sex workers and holding them in rehab for several months is a practical practice that does not really reflect the empirical facts.

Bandung City Government does not have a product of policy such as the regional regulations that specifically and the focus discusses about how the government of Bandung addressed the strictly prolific phenomenon of increasingly vibrant in the city of Bandung. So far the government of Bandung only rely on Local Regulations Bandung No. 3 of 2005 and updated with Local Regulations Bandung No. 11 of 2005 on the Implementation of Order, Cleanliness and Beauty.

The local regulations are so wide in scope that they are ineffective in dealing with permanent prostitution, openly less disguised prostitution. The scope of this regional regulation is broad enough, for the phenomenon of prostitution in this Local Regulation only prohibits the community to commit immorality or prohibition of facilitating such actions to provide a home used for immoral activities. A local regulation that deals mostly with garbage and the beauty of the city how it will focus on finding the best way out for Bandung society is related to the phenomenon of prostitution which explicitly emerges by bringing all the links with the economic, social, political, and even cultural aspects that make the phenomenon of prostitution it's so hard to get rid of.

Meanwhile, in Indonesia there is not a single article in the Kitab Undang-undang Hukum Pidana (KUHP) that explicitly threatens the criminal against prostitutes. There are only three chapters that threaten punishment to anyone whose livelihood or habits intentionally establish or facilitate lewd deeds with others (pimp). This is threatened in article 296 of the KUHP, then those who traffick women (including immature men) are

${ }^{7}$ Healthy Department of Bandung, 2015. 
mentioned in article 297 of the KUHP. And the last is the brokers (intermediaries) in bringing prostitutes with their customers and taking advantage of prostitution, threatened in article 506 of the KUHP. Thus the prostitute himself is not explicitly threatened by criminal law, as it is "prostitution itself is not crime," says Denise Winn. (Purnomo, Siregar, 1983:10) However, these prostitutes are repressively and discriminately perpetrated, dragged, eradicated and silenced in the name of improper government enforcement.

Bandung City Government does not have a clear view in interpreting the phenomenon of prostitution so that the government does not have an ideal direction and vision in the process of handling. The handling of prostitution has been done without touching and analyzing the reasons why this prostitution practice still exists and develops. The act of cleaning prostitution by arresting a prostitute woman seems to solve the problem. Whereas in fact, the existence of this prostitution world is encouraged and supported by a very strong and distinctive system mechanism. Not necessarily prostitutes peddling him safely displaying the beauty of his fantastic body and muttering compelled gedempt-flattering seduction to have sex with men and then easily earn money

There are several aspects that support this drama to walk based on a systematic scenario following the market mechanism of lust commercial commerce.

\section{CONCLUSION}

The phenomenon of prostitution in Bandung is not easy to be controlled let alone eliminated. The place or location of prostitution that is the location of the gathering of sex workers may be closed and destroyed. However, human prostitutes and all elements of perpetrators in the world of prostitution is not possible to be eliminated or destroyed just like that, from the results of this study can be seen that the handling of repressive in the form of eradication in fact not something that is absolutely done by the Government of Bandung. The handling of prostitution can be done in a variety of ways more best, namely: Preventive handling with a sociological and humanist approach. Current regional legislation is discriminatory and unsuccessful in prostitution is also necessary to create new policy formulas and focus as an effective prostitution model. The current prostitution only collects and captures female sex workers only and for masher men, pimps, pimps to entertainment establishments in prostitution. It is precisely those who master a very strong prostitution system. Those who have never given a firm action. The prostitution system is created because of many external factors that support the growing prostitution phenomenon. Women prostitutes are victims of helplessness and poverty. Furthermore, they are the children of the illegitimate relationship between the landlord and the government.

\section{ACKNOWLEDGMENT}

When I examine the phenomenon of prostitution with this Government Science framework, it arrives at the realization that just how many government affairs and problems are waiting to be resolved. All that is correlated with various aspects that must be seen with glasses from various locations of different viewpoints, and require a source of support from various scholars as well as all the trivia of concepts and theories. For months I have been watching the world of prostitution in the city of Bandung, had tried to be an intermediary (brokers) until a few nights into a prostitute motorcycle taxi, gave birth to an increasingly strong interest, making more and more keen to uncover the veils of life of the prostitutes, and what the government has done to all of them. Highest thanks to Prof. Dr. H. Dede Mariana, M.Sc. and Prof. Dr. H. Utang Suwaryo, MA. for his diverse and valuable explanations, and always willing to offer free consultations and enlightening suggestions. I would like to thank my teachers and friends at University of Singaperbangsa Karawang and Padjadjaran University. I also thank my parents, my best friend Bang Acung, and my sweetheart: Rika Puji Astuti for all the warmth given in accepting all my complaints.

\section{REFERENCES}

[1] Agustino. Leo, Dasar-Dasar Kebijakan Publik. Bandung: Alfabeta, 2008.

[2] Berger. Peter L, \& Luckmann, Thomas, Tafsir Sosial atas Kenyataan: Risalah tentang Sosiologi Pengetahuan. Jakarta: LP3ES, 2012.

[3] Brouwer. M.A.W, Perjalanan Spiritual: Dari Gumujeng Sunda, Eksistensi Tuhan, Sampai Siberia. Jakarta: Kompas, 2003.

[4] Creswell. J.W, Research Design Pendekatan Kualitatif, Kuantitatif dan Campuran. Yogyakarta: Pustaka Pelajar, 2012.

[5] Dunn. William N, Pengantar Analisis Kebijakan Publik Ed. II. Yogyakarta: Gadjah Mada University Press, 1998.

[6] Foucault. Michel, Seks dan Kekuasaan: Sejarah Seksualitas. Jakarta: Gramedia. 2000.

[7] Freud. Sigmund, Manifesto Seksualitas. Yogyakarta: Titah Surga, 2014.

[8] Fromm. Erich, Cinta, Seksualitas dan Matriarki: Kajian Komprehensif Tentang Gender. Bandung: Jalasutra, 2007.

[9] Garna. J.K, Penelitian dalam Ilmu Pemerintahan. Bandung: Primaco Akademika, 2000.

[10] Giddens. Anthony, Transformation of Intimacy: Seksualitas, Cinta dan Erotisme dalam Masyarakat Modern. Jakarta: Fresh Book. 2004.

[11] Hoogerwerf, Ilmu Pemerintahan. Jakarta: Erlangga, 1983.

[12] Kadir. Hatib Abdul, Tangan Kuasa dalam Kelamin: Telaah Homoseks, Pekerja Seks, dan Seks Bebas di Indonesia. Yogyakarta: INSISTPress. 2007.

[13] Kuswarno. Engkus, Fenomenologi: Konsepsi, Pedoman, dan Contoh Penelitian. Bandung: Widya Padjajaran, 2013.

[14] Labolo. Muhadam, Memahami Ilmu Pemerintahan: Suatu Kajian, Teori, Konsep dan Pengembangannya. Jakarta: PT. RajaGrafindo Persada, 2013.

[15] Lim. Gerrie, Invisible Trade (Perdagangan Terselubung): Seks Komersil Kalangan Atas Singapura. Jakarta: GagasMedia, 2005.

[16] MacIver. Robert M, The Web of Government. New York: The Macmillan Company, 1963.

[17] Pitoyo, The End of Saritem: Studi Komunikasi Politik. Bandung: Simbiosa Rekatama Media, 2013.

[18] Poelje. Van G.A, Pengantar Umum Ilmu Pemerintahan. Jakarta: N.V Soeroengan, 1953.

[19] Purnomo. Tjahjo, \& Siregar. Ashadi, Dolly: Membedah Dunia Pelacuran Surabaya, Kasus Komplek Pelacuran Dolly. Jakarta: Grafiti Pers, 1983.

[20] Roosevelt. Clinton, The Science of Government. New York: Dean \& Trevett, 1841. 
[21] Sedyaningsih. Endang R, \& Mamahit, Perempuan-perempuan Kramat Tunggak. Jakarta: Kepustakaan Populer Gramedia, 2010.

[22] Truong. Thanh-Dam, Seks Uang dan Kekuasaan: Pariwisata dan Pelacuran di Asia Tenggara. Jakarta: LP3ES, 1992. 